\title{
An Integrated Reconstruction of the Multiannual Wave Pattern in the Gulf of Naples (South-Eastern Tyrrhenian Sea, Western Mediterranean Sea)
}

\author{
Simona Saviano ${ }^{1,2, *(\mathbb{D}}$, Daniela Cianelli ${ }^{2,3}$, Enrico Zambianchi ${ }^{1,2}\left(\mathbb{D}\right.$, Fabio Conversano ${ }^{3(\mathbb{C}}$ \\ and Marco Uttieri ${ }^{2,4}$ (D) \\ 1 Department of Science and Technologies, Parthenope University of Naples, Centro Direzionale Is.C4, \\ 80143 Naples, Italy; enrico.zambianchi@uniparthenope.it \\ 2 CoNISMa (National Inter-University Consortium for Marine Sciences), Piazzale Flaminio, 00196 Rome, Italy; \\ daniela.cianelli@szn.it (D.C.); marco.uttieri@szn.it (M.U.) \\ 3 Department of Research Infrastructures for MArine Biological Resources, Stazione Zoologica Anton Dohrn, \\ Villa Comunale, 80121 Naples, Italy; fabio.conversano@szn.it \\ 4 Department of Integrative Marine Ecology, Stazione Zoologica Anton Dohrn, Villa Comunale, \\ 80121 Naples, Italy \\ * Correspondence: simona.saviano@uniparthenope.it
}

Received: 15 April 2020; Accepted: 20 May 2020; Published: 23 May 2020

\begin{abstract}
Surface gravity waves retrieved by a network of HF (High Frequency) radars and measured in situ by an ADCP (Acoustic Doppler Current Profiler) current meter connected to an elastic beacon were used to carry out a multiple-year characterization of the wave field of the Gulf of Naples (south-eastern Tyrrhenian Sea, western Mediterranean). The aim of the work was to create a climatology of the study area and to demonstrate the potential of an integrated platform for coastal studies. The patterns recorded by the different instruments were in agreement with the wave climatology of the southern Tyrrhenian Sea as well as with previous scores for the same area. The results presented in this work also highlight seasonal and interannual consistency in the wave patterns for each site. In a wider context, this study demonstrates the potential of HF radars as long-term monitoring tools of the wave field in coastal basins, and supports the development of integrated observatories to address large-scale scientific challenges such as coastal ocean dynamics and the impact of global change on the local dynamics.
\end{abstract}

Keywords: Gulf of Naples; HF radar; ADCP; augmented observatory; wave field

\section{Introduction}

The monitoring of the wave field over several years is a fundamental prerequisite for the knowledge and definition of the wave climate of a given basin. Wave climatology has direct consequences on the design of offshore and coastal structures and their management as well as on renewable energy assessment [1]. Wave climate can be defined as the distribution of significant wave height (Hs), period $(T)$, and direction $(\theta)$ averaged over a defined period for a given site $[2,3]$. While for the open sea, the wave climate can be assumed as rather invariant and may be similar over large distances [3], it might be profoundly modified in coastal areas (i.e., sea level rise, climate change) $[4,5]$.

The correct assessment of wave climatology is strongly dependent on the number of years included in the analysis [3]. Wave climatology has been traditionally based on moored buoys, returning accurate but spatially limited measurements [6,7]. More recently, the availability of long-term satellite altimetry data and the implementation of third-generation wave models have paved the way to wave climate studies from global [8] to regional scales [9], allowing for the recreation of the wave field not directly 
covered by in situ buoys. Satellite altimetry data allow for the estimation of wave climate statistics with a resolution of $1^{\circ}$ to $2^{\circ}$, depending on the satellite spatial and time coverage $[10,11]$. Wave models, instead, have enabled the development of wave climatology based on more extensive wind data (i.e., wind reanalysis), permitting the creation of global to regional scale retesting [12,13].

In this context, HF (High Frequency) radars can provide high-resolution (both spatial and temporal) information and near real-time monitoring of the wave field in coastal areas, with virtually continuous functioning over several years, thus potentially representing a valid alternative to wave buoys. HF radars employ the echo backscattered by the rough sea surface, according to the physics first described by Crombie [14]. In the presence of Bragg scattering, the signal is reflected off waves with a wavelength exactly half that emitted by the radar and travelling radially with respect to the antenna itself (either approaching or moving away from it). The spectral analysis of the electromagnetic signal reveals a Doppler-shifted peak, resulting from the current field within which the wave is propagating and from the theoretical wave speed [15]. The first-order echoes generally produce strong signals, used for robust measurements of surface currents [16,17]. Additional contributions to the Doppler signature are due to nonlinear wave interactions and double-scattering processes leading to second-order echoes [18], which, in turn, can be used to extract information on the wave field itself $[17,19,20]$. To date, studies using HF radars to evaluate wave features have been mostly limited to short periods (up to a few months; e.g., [18,21-27], or to specific events (e.g., tsunamis [28]; storms [29]). Only a few works have so far delved into the assessment of wave retrieval by HF radars over long periods, in the UK [30], in Central California (USA) [31], in Galway Bay (IE) [32], in the Gulf of Naples (IT) [33], and along the Galician coast (ES) [34], creating a new benchmark for augmented observatories.

To date, however, no study has yet made use of HF radar-derived wave measurements to build the wave climatology of a given area. In the present contribution, we intend to raise the bar for HF operators by integrating multiannual HF radar wave measurements with in situ recordings collected through an ADCP (Acoustic Doppler Current Profiler) to build the climatology of a coastal basin, the Gulf of Naples (GoN) (south-eastern Tyrrhenian Sea, western Mediterranean). HF radar derived measurements in the GoN have been previously compared with those recorded by a fixed buoy installed outside the coverage area of the radars [33] and with model simulations [35] returning good agreement in the seasonal patterns, reconstructed by the different platforms and in the statistical comparison of the wave parameters themselves (e.g., with normalized root mean square error in the order of few centimeters for Hs). The HF system operating in the GoN is the longest running in Europe [36], being operative since 2004 (Figure 1). Wave recording and analysis was initialized in May 2008 and ended in December 2012, permitting the collection of data over several consecutive years, providing the unique opportunity of depicting typical seasonal dynamics and highlighting characteristic features during storm conditions. Complimentary to the HF data, in this contribution, the wave recordings collected by means of a bottom-mounting ADPC interlocked with a MEDA elastic beacon operating in the GoN were included in the analysis, with reference to the period November 2015-July 2018. This integrated approach allowed the creation of a dataset spanning more than seven years, here used to construct a multiple-year pattern of wave conditions in the coastal area of the GoN. In particular, thanks to the geometry of the HF system and to the positioning of the MEDA elastic beacon, the dataset was analyzed to pinpoint the specific wave patterns of three different sectors of the basin and to reconstruct their seasonal patterns.

The results confirm previous records from the same basin [33,37-40], evidencing specific features depending on the season and on the sub-basin investigated. The findings presented in this work are additionally in line with the general wave climate of the southern Tyrrhenian Sea [41], indicating a commonality with the large-scale processes. As a wider-breath implication, the results shown here emphasize the possibility of resorting to HF radars as a long-term platform to monitor the wave field in coastal areas, and support the adoption of an integrated, multi-platform approach to build a robust observation system, retrieving near real-time data for the proper management and monitoring of coastal areas. 


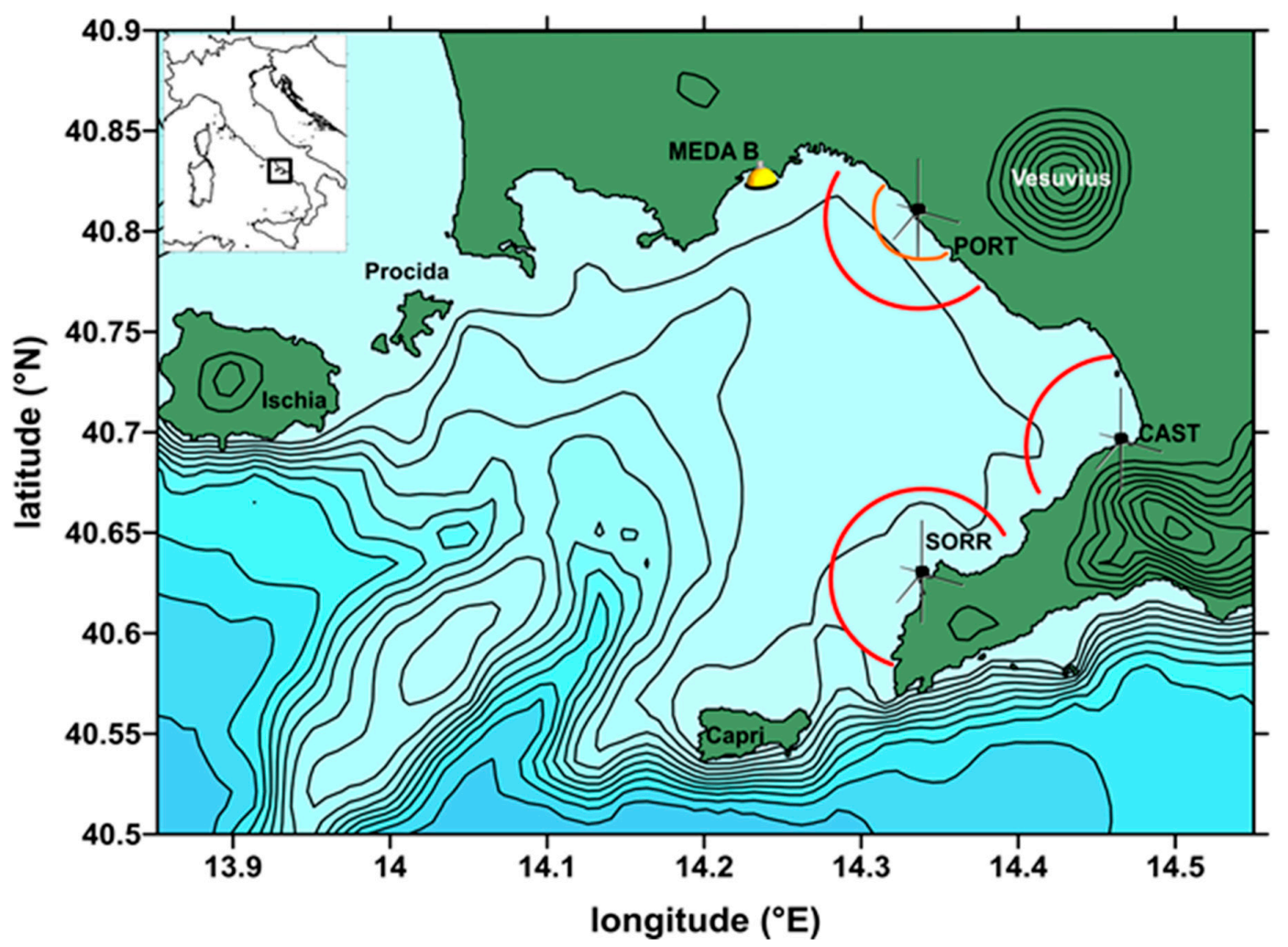

Figure 1. Map of the Gulf of Naples (south-eastern Tyrrhenian Sea, western Mediterranean Sea; see inset) with the locations of the three HF radar sites (antenna icons) and of ADCP connected to the MEDA B elastic beacon (buoy icon). The annuli centered on HF antennas represent RC5 (red) and RC2 (orange) (see text for details). The bathymetric and orographic contours were spaced every $100 \mathrm{~m}$; elevation isolines were plotted starting from $300 \mathrm{~m}$ for graphical reasons.

\section{Study Area}

The GoN is a marginal sub-basin of the south-eastern Tyrrhenian Sea, characterized by an intricate bottom topography (including two deep canyons) and orography (Vesuvius volcano, hills in the urban area of Naples city, Lattari mountains on the south) [42-44]. The area is subject to intense anthropic pressure [45-48], but at the same time it is particularly rich in terms of biodiversity [49-53] and punctuated by numerous coastal archeological sites [54-56], with the presence of habitats with a high value of natural capital stock [57].

The surface circulation of the GoN is mainly driven by the local wind field, with the creation of specific patterns affecting both the physical and biological processes developing in the area [42,58-63]. During the winter months, the predominant and most intense winds come from the NNE and NE directions; in spring and autumn, the principal directions are NE and SW, while in summer, winds are generally weaker than the rest of the year [64]. This general wind regime is associated with numerous low pressure systems passing over the basin, with frequent stormy and windy events principally during winter and autumn. In contrast, in spring and summer, the setup and reinforcement of the Azores anticyclone, and in the latest years of the African anticyclone, determine the onset of a stable, moderate breeze system $[65,66]$.

Previous investigations on the wave characteristics in the GoN, using non-directional wave buoys [37-40] and HF radars [33], have shown a strong seasonality related to the meteorological features of the study area, resulting in severe sea storms in winter and autumn, and lower wave heights due to stable and persistent high-pressure field in spring-summer [42,58,64]. A year-long analysis using HF radars [33] showed that, on average, wave heights in the inner sub-basins of the GoN ranged from 1.19 to $1.70 \mathrm{~m}$, while areas closer to the Tyrrhenian Sea scored higher values (1.77-2.38 m) with 
typical wave periods between 6 and $8 \mathrm{~s}$. Storms impacting the GoN occur mostly in winter and autumn, and are typically of the frequent extratropical type (i.e., linked to the oscillation of polar front), covering large areas and remaining in the offshore sectors for a significant time, so that large waves can build up [67]. In some cases, storms can also be driven by the Mediterranean low pressure systems [67]. In such extreme events, wave heights can be significantly higher than the average records, often getting values greater than $3 \mathrm{~m}$.

It is worth underlining here that the previous investigations for the GoN were focused on short time windows (typically from a few weeks to months) and included the use of one instrument only. The results thus collected provide information uniquely for one site. Only in [33], was a year-long investigation with three HF radars performed, retrieving the first description of the wave field in three different areas of the GoN.

\section{Materials and Methods}

The HF radar network installed in the GoN, operated by the Department of Science and Technology at the 'Parthenope' University of Naples, is a system composed of three SeaSonde $25 \mathrm{MHz}$ transceiving stations (CODAR Ocean Sensors, Mountain View, CA, USA) located in Portici (PORT), Castellammare di Stabia (CAST), and Massa Lubrense (SORR) (Figure 1; for its characteristics, data validation, and use in numerical models see $[58,63,68])$.

In SeaSonde systems, a Pierson-Moskowitz model [20] is used to extract wave parameters (significant wave height $\mathrm{Hs}_{\mathrm{HF}}$, direction $\theta_{\mathrm{HF}}$, and centroid period $\mathrm{T}_{\mathrm{HF}}$ ) from the second-order spectrum. In the present work, wave parameters were measured and averaged along annuli (range cells, RCs) centered on the antenna and regularly spaced every $1 \mathrm{~km}$. For a $25 \mathrm{MHz}$ system, the operational range for $\mathrm{Hs}_{\mathrm{HF}}$ is typically bounded between 0.50 and $4.00 \mathrm{~m}$. Hs $\mathrm{HF}$ below $0.50 \mathrm{~m}$ are characteristic of weak second-order echoes [26], whereas at $\mathrm{Hs}_{\mathrm{HF}}>4.00 \mathrm{~m}$ the wave spectrum saturates and retrieval of wave parameters is unachievable [20]. As a QA/QC (Quality Assurance/Quality Control) procedure, $\mathrm{Hs}_{\mathrm{HF}}$ values over the theoretical upper threshold were checked for consistency with the wave pattern recorded in the same time window, following the protocol designed in [33]. Moreover, waves should have a period of $5 \mathrm{~s}$ at least, or longer if the noise floor increases, which is to be interpreted by the radar [20]. Wave measurements were performed over 12 RCs at the PORT and SORR sites, and over 15 RCs in CAST, by using the proprietary CODAR software (Seasonde Radial Suite R7u2), and were provided every $10 \mathrm{~min}$ by averaging four spectra falling within the given time window. Based on previous analysis in [33], wave measurements from RC5 (i.e., the RC representative of the annulus 5-6 km far from the antenna) were selected as representative of an operational trade-off between distance from the coast (sufficient echo intensity) and depth (deep water condition; mean depths over the annuli: PORT: $117 \mathrm{~m}$; CAST: $65 \mathrm{~m}$; SORR: $98 \mathrm{~m}$ ). To perform a more accurate comparison between the measurements collected by PORT and the ADCP installed within the MEDA framework (see below for details), for this specific site RC2 (i.e., representative of the annulus covering the area between 2 and $3 \mathrm{~km}$ for the antenna, mean depth over the annulus: $70 \mathrm{~m}$ ) was also taken into account. In the present study, wave data collected from all three sites over the period between May 2008 and December 2012 were used. This time window corresponded to an optimal multiannual functioning of the network (i.e., system calibration and validation, minimal data gaps), ensuring the construction of a robust dataset.

The elastic beacon MEDA B managed by the Stazione Zoologica Anton Dohrn is located at a distance of about $450 \mathrm{~m}$ from the coast of Naples on a seabed $17.5 \mathrm{~m}$ deep (Figure 1). MEDA B has been operating since November 2015. An ADCP current meter is connected to the elastic beacon on the bottom, not far from the anchor of the MEDA. It is equipped with a sensor for directional wave measurements indicating how much wave energy exists $\left(\mathrm{Hs}_{\mathrm{B}}\right)$, from which direction $\left(\theta_{B}\right)$, and at what frequency $\left(\mathrm{T}_{\mathrm{B}}\right.$, peak period) (Teledyne RD Instruments-WHSW $600 \mathrm{kHz}$ model with $\mathrm{NEMO}^{\mathrm{TM}}$ real-time wave processing module). The module is configured to sample wave data every $20 \mathrm{~min}$ by recording spectra, which are then averaged every hour (2100 pings at $2 \mathrm{~Hz}$ ). Data referring to the 
time period considered were $\mathrm{QA} / \mathrm{QC}$ checked using the same protocol adopted for HF radar data. This ensured obtaining a coherent dataset, without spikes or incongruent values. Characteristics of the measurement systems and the dataset are shown in Table 1.

As a first step in the data analysis, an overview of the records was produced as Hs time series, conveying an immediate, qualitative description of the interannual patterns for each platform. In addition, wave recordings were seasonally grouped, divided in three-month seasons (January-March: winter; April-June: spring; July-September: summer; October-December: autumn) based on the specific evidences discussed in [61], showing the onset of typical spring-summer climatologic features (e.g., stable high pressure systems, breeze regimes) in April. This categorization differs from the typical classification given by [69], more realistically mirroring the climatology of the GoN.

The wave field characterization for all the selected periods was carried out over the dataset to distinguish different basin behavior consequent to different meteorological forcing.

Table 1. Characteristics of the measurement systems and the dataset.

\begin{tabular}{lcc}
\hline & SeaSonde Systems & ADCP \\
\hline Parameters & & \\
\hline Significant wave height $(\mathrm{Hs})$ & $\mathrm{x}$ & $\mathrm{x}$ \\
\hline Mean Direction $(\theta)$ & $\mathrm{x}$ & $\mathrm{x}$ \\
\hline Centroid period $\left(\mathrm{T}_{\mathrm{HF}}\right)$ & $\mathrm{x}$ & November 2015-December 2018 \\
\hline Peak period $\left(\mathrm{T}_{\mathrm{B}}\right)$ & May 2008-December 2012 & 21,590 \\
\hline Time series & 81,888 & $1 \mathrm{~h}$ \\
\hline Number of observations & $10 \mathrm{~min}$ & \\
\hline Acquisition Time & & \\
\hline
\end{tabular}

Descriptive and numerical statistics were then employed to analyze the seasonally grouped results $(\mathrm{Hs}, \mathrm{T}$, and $\theta$ ). Data were interpreted using standard descriptors (mean, median, standard deviation, minimum and maximum values). A more detailed comparison was additionally performed by means of seasonal boxplots, a standardized way of displaying the distribution of data based on five descriptors: 5th percentile, 25th percentile, median, 75th percentile, and 95th percentile. In the simplest boxplot, the central rectangle spans the first quartile to the third quartile (interquartile range, IQR). A segment inside the rectangle shows the median and "whiskers" above and below the box show the locations of the 5th and 95th percentiles. Data outside this range are displayed as single outliers. In the present analysis, the HF radar outliers were checked for consistency based on the results obtained in previous studies $[33,35]$ and retained in the analysis without being discarded as aberrant values. Boxplots visually overlapping in terms of IQR identified statistically similar records.

Polar rose diagrams were employed to visualize the directional distribution of waves for each site. Additionally, in the plots, a radial scale reported the frequency associated to each directional class, while spokes were color-coded according to Hs ranges. The multiple-year study was complemented by the joint frequency distribution. Data were grouped in eight $\mathrm{Hs}$ classes of $0.50 \mathrm{~m}$ each, and in direction sectors with an angle of $15^{\circ}$. The number of occurrences for each class was calculated by dividing the number of events falling within the considered class and the total number of data. The statistical indicator taken into account was consequently the joint frequency distribution of significant Hs with respect to $\theta$.

A storm can be defined as a strong atmospheric perturbation accompanied, among other elements, by a low pressure system and intense winds. At sea, the most direct effects are the increase in Hs, and under certain conditions, in sea level (storm surge) [70]. In the GoN, such events are more frequently recorded in autumn and winter, but also occasionally in spring. In the literature, different methods for the identification of sea storms can be found, generally considering a parameter exceeding a threshold 
over a certain period (e.g., Hs [71], energy flux [72], wind [73]). In the framework of the present analysis, to investigate extreme events the storm energy content $\mathrm{E}\left(\mathrm{m}^{2} \mathrm{~h}\right)$ [71] was calculated according to:

$$
E=\int_{t 1}^{t 2} H s^{2} \mathrm{dt}
$$

where $t_{1}$ and $t_{2}$ define the storm duration. In line with the available literature, in order to identify storm events in the dataset analyzed, observations of $\mathrm{Hs}>1.25 \mathrm{~m}$ over a period longer than six hours were taken into consideration $[71,74]$.

\section{Results}

\subsection{Interannual Patterns}

The interannual Hs time series recorded by the HF radars and by the ADCP are shown in Figure 2. The time series clearly indicated seasonal patterns, with higher Hs in autumn/winter due to the higher occurrence of depression systems, and lower scores in spring/summer in association with the establishment of stable high pressures [33,64]. With reference to HF radars measurements, as expected from previous evidences [33], PORT and CAST recorded $\mathrm{Hs}_{\mathrm{HF}}$ values lower than the concomitant ones by the SORR site, which is closer to the open Tyrrhenian waters. The visual comparison of the time series recorded at RC5 and RC2 at the PORT site showed no significant difference in $\mathrm{Hs}_{\mathrm{HF}}$ as the waves moved shoreward, as long as the deep water condition was respected. As expected, $\mathrm{Hs}_{\mathrm{B}}$ recorded by the ADCP were lower than those obtained by the HF radars. This evidence can be explained by different factors, namely, the sheltered position of the ADCP with respect to HF antennas, determining the refraction of incoming waves and reduction of $\mathrm{Hs}$ [75] and close vicinity of the gauge to the coastline.

The variability in Hs was further investigated at seasonal scale through the characterization of measurements by means of statistical descriptors, as summarized in Table 2. This was coupled with the comparison of the boxplots reported in Figure 3. Overall, the integration of the different approaches confirmed what qualitatively emerged in the visual analysis of the time series shown in Figure 2, namely: more intense wave conditions at SORR; no significant differences between PORT and CAST, which both covered the internal part of the basin, nor between RC5 and RC2 at PORT; and lower Hs at the MEDA B location. The extreme maximum $\mathrm{Hs}_{\mathrm{HF}}$ recorded by the $\mathrm{HF}$ radars were compatible with previous investigations for the same basin [33,35], although falling outside the theoretical radar detection limits (see [33] for an extensive discussion). The discordance in the mean value of the seasonal data can be partly attributed to HF radar low sea-state limitations [33] and to environmental noise, which decreases the accuracy of raw measurements. It is evident from Figure 2 that $\mathrm{Hs}_{\mathrm{B}}$ went below the $0.5 \mathrm{~m}$ threshold, instead the HF radars could not detect the waves efficiently.

The seasonal polar rose diagrams shown in Figure 4 enabled the immediate visual identification of the most frequent wave directions $\theta$. Site-specific features depended upon the local bathymetry and orography, pointing to spatially variable characteristics of the wave field for the different sub-basins of the GoN. The ADCP recordings showed a strong directionality in winter, spring and fall with waves approaching the shore from the SW, while during the summer a high percentage of waves with low height $(<0.5)$ was observed from a broader sector $\left(95^{\circ}-265^{\circ}\right)$. All HF radar observations had typically unimodal seasonal directional climates. Using the color-coding of the spokes and the radial axis of the roses, it was possible to identify the frequency of occurrence for each site in terms of Hs along each angular sector considered. The color labelling of the spokes confirmed that the ADCP typically recorded lower Hs compared to the HF radars, which instead monitored more offshore sectors. At the same time, rose diagrams visually communicated the occurrence of higher $\mathrm{Hs}_{\mathrm{HF}}$ at SORR than at PORT and CAST.

The site-specific relationship between $\mathrm{Hs}$ and $\theta$ was further confirmed by the joint frequency distributions of the multiannual datasets (Table 3). The ADCP recorded lower Hs, with a predominance 
of occurrences $(>75 \%)$ from $165^{\circ}-195^{\circ}$. On the other hand, as already deduced from the previous analyses, the HF radars recorded higher Hs. The directional spreading of PORT $\left(195^{\circ}-225^{\circ},>80 \%\right)$ and CAST $\left(270^{\circ}-300^{\circ},>96 \%\right)$ was similar to the ADCP one, whereas SORR displayed a wider $\theta$ range $\left(285^{\circ}-330^{\circ}, 79 \%\right)$. The percentage of captured data with $\mathrm{Hs}<0.5 \mathrm{~m}$ was low for all HF sites due to instrumental intrinsic limitations, as discussed by [76] and the references therein.

The analysis carried out in the present work also focused on the assessment of the wave period (T) estimates from the HF radars $\left(\mathrm{T}_{\mathrm{HF}}\right)$ and the ADCP $\left(\mathrm{T}_{\mathrm{B}}\right)$. $\mathrm{T}_{\mathrm{HF}}$ returned a period representing the centroid of the model being fitted to the second-order Doppler spectrum, while $\mathrm{T}_{\mathrm{B}}$ provided the peak period measured by the ADCP. As discussed in [31], $\mathrm{T}_{\mathrm{HF}}$ can be assumed as a stable estimator just like the mean period retrieved by wave buoys. The boxplots for $\mathrm{T}_{\mathrm{HF}}$ and $\mathrm{T}_{\mathrm{B}}$ (Figure 5) show that the HF radars returned statistically comparable values, grouped in the 6-8 s window, in line with the invariance of wave period. $T_{B}$, on the other hand, always returned smaller values (4-6s), but typically with higher statistical dispersion around the median compared to $\mathrm{T}_{\mathrm{HF}}$. For each site and platform, consistent values were recorded for the different seasons.

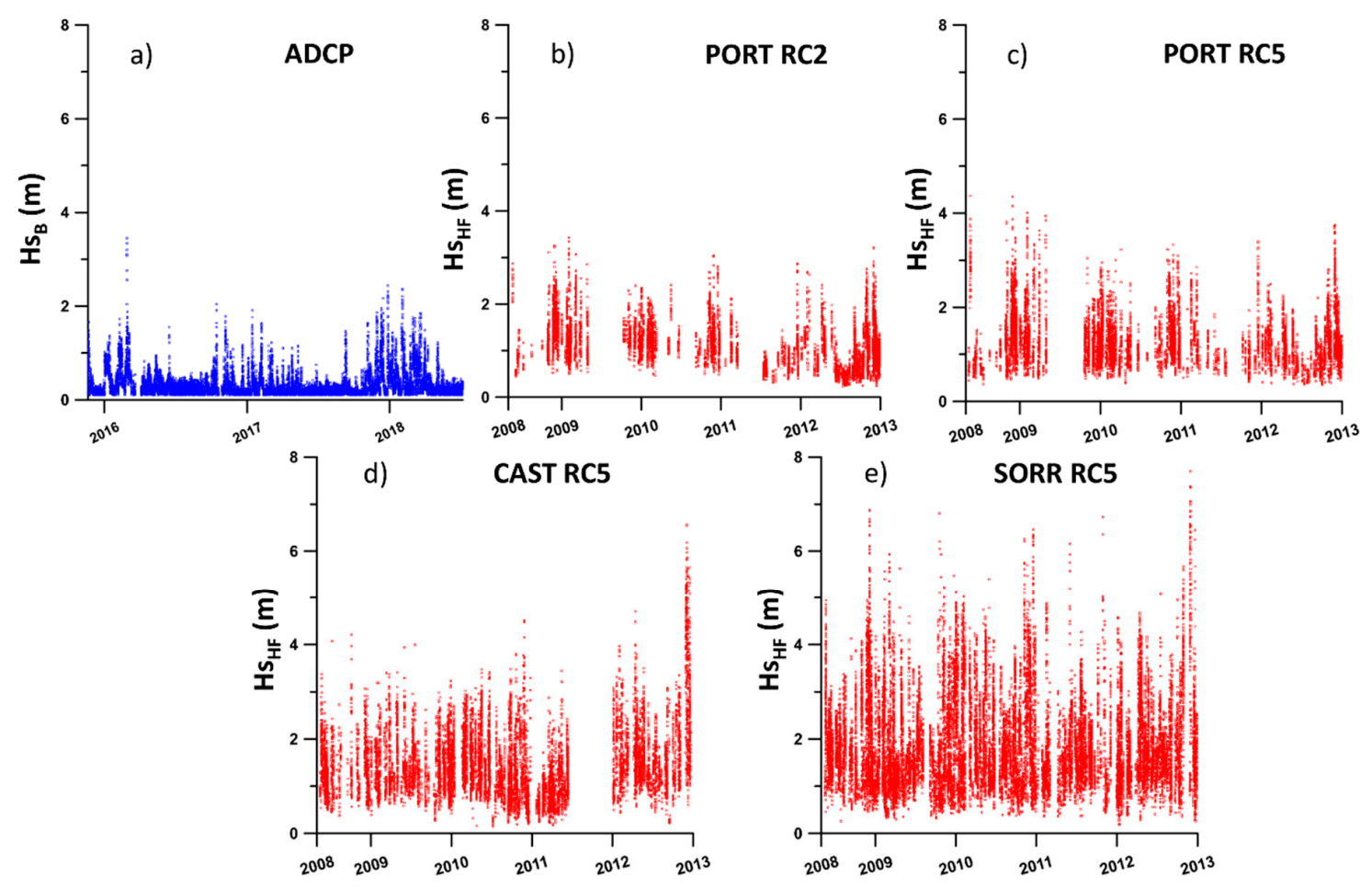

Figure 2. Hs time series for the ADCP $\left(\mathrm{Hs}_{\mathrm{B}}\right.$; blue, panel a) and the three $\mathrm{HF}$ radar sites $\left(\mathrm{Hs}_{\mathrm{HF}}\right.$; red, panels $\mathbf{b}-\mathbf{e})$. For the PORT site, the $\mathrm{Hs}_{\mathrm{HF}}$ values recorded both at $\mathrm{RC} 2$ and RC5 are plotted. 


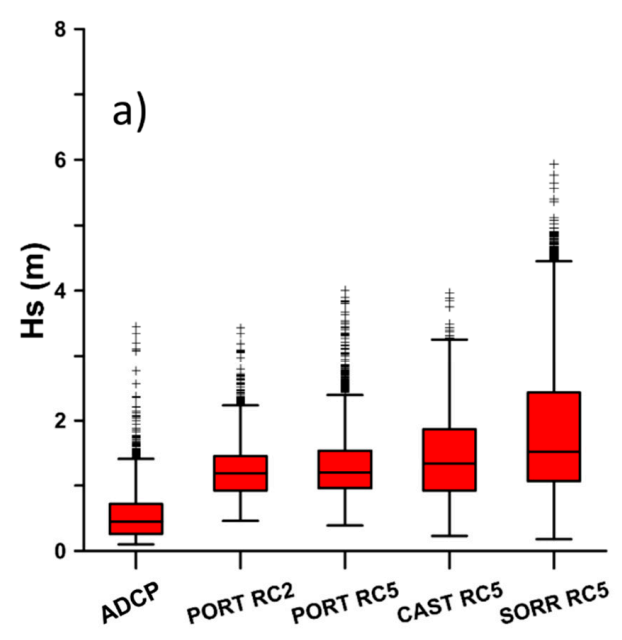

WINTER

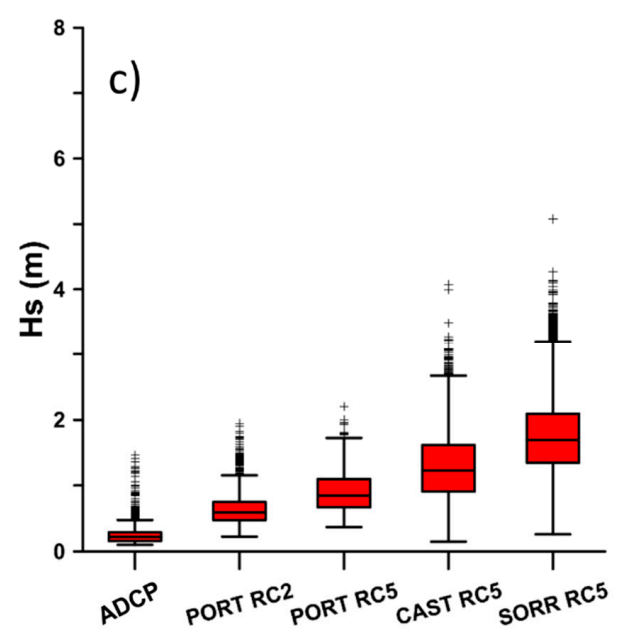

SUMMER

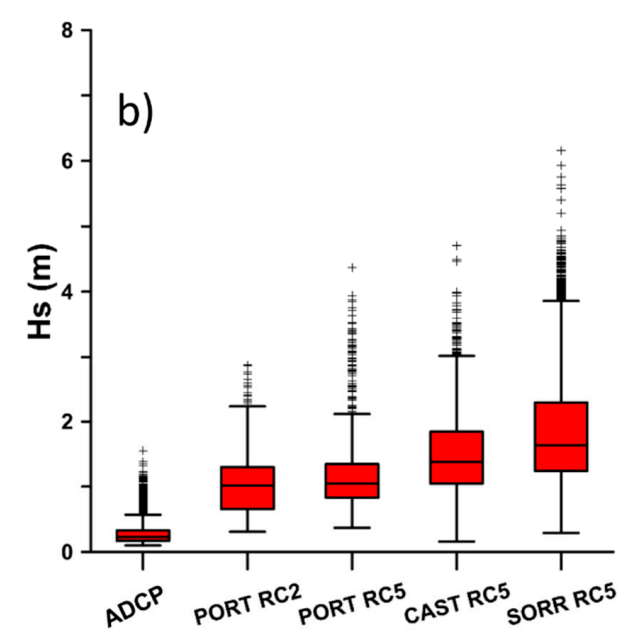

SPRING

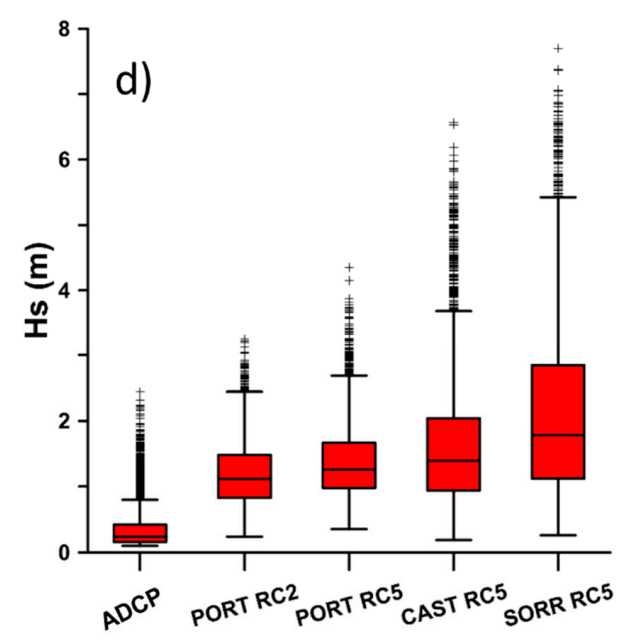

AUTUMN

Figure 3. Cumulative seasonal Hs boxplots recorded by the $\mathrm{ADCP}\left(\mathrm{T}_{\mathrm{B}}\right)$ and the HF radars $\left(\mathrm{T}_{\mathrm{HF}}\right)$. For the PORT site, both RC2 and RC5 data are shown. The panels show the different seasons: (a) winter; (b) spring; (c) summer; and (d) autumn.

Table 2. Statistical descriptors (min: minimum value; max: maximum value; mean: mean value; std: standard deviation; median: median value) of the seasonal Hs values recorded by the HF radars and the ADCP. For the PORT site, both RC2 and RC5 are included.

\begin{tabular}{|c|c|c|c|c|c|c|c|c|c|c|}
\hline & PORT-RC2 & PORT-RC5 & CAST-RC5 & SORR-RC5 & ADCP & PORT-RC2 & PORT-RC5 & CAST-RC5 & SORR-RC5 & ADCP \\
\hline Hs (m) & & & WINTER & & & & & SPRING & & \\
\hline $\min$ & 0.46 & 0.39 & 0.23 & 0.18 & 0.10 & 0.31 & 0.37 & 0.16 & 0.29 & 0.10 \\
\hline $\max$ & 3.43 & 3.95 & 3.90 & 5.90 & 3.45 & 2.87 & 4.30 & 4.70 & 6.10 & 1.55 \\
\hline mean & 1.24 & 1.3 & 1.43 & 1.84 & 0.54 & 1.06 & 1.18 & 1.49 & 1.85 & 0.28 \\
\hline std & 0.43 & 0.52 & 0.63 & 1.02 & 0.34 & 0.48 & 0.55 & 0.61 & 0.83 & 0.17 \\
\hline \multirow[t]{2}{*}{ median } & 1.19 & 1.20 & 1.34 & 1.52 & 0.45 & 1.01 & 1.05 & 1.38 & 1.63 & 0.23 \\
\hline & PORT-RC2 & PORT-RC5 & CAST-RC5 & SORR-RC5 & ADCP & PORT-RC2 & PORT-RC5 & CAST-RC5 & SORR-RC5 & ADCP \\
\hline Hs (m) & \multicolumn{5}{|c|}{ SUMMER } & \multicolumn{5}{|c|}{ AUTUMN } \\
\hline $\min$ & 0.22 & 0.37 & 0.43 & 0.26 & 0.1 & 0.24 & 0.35 & 0.19 & 0.26 & 0.10 \\
\hline $\max$ & 1.94 & 2.20 & 1.23 & 5.00 & 1.46 & 3.25 & 4.30 & 6.50 & 7.20 & 2.44 \\
\hline mean & 0.65 & 0.92 & 0.74 & 1.76 & 0.24 & 1.19 & 1.38 & 1.63 & 2.08 & 0.35 \\
\hline std & 0.27 & 0.33 & 0.56 & 0.63 & 0.13 & 0.49 & 0.56 & 0.99 & 1.20 & 0.32 \\
\hline median & 0.59 & 0.85 & 1.23 & 1.70 & 0.22 & 1.11 & 1.26 & 1.39 & 1.78 & 0.24 \\
\hline
\end{tabular}



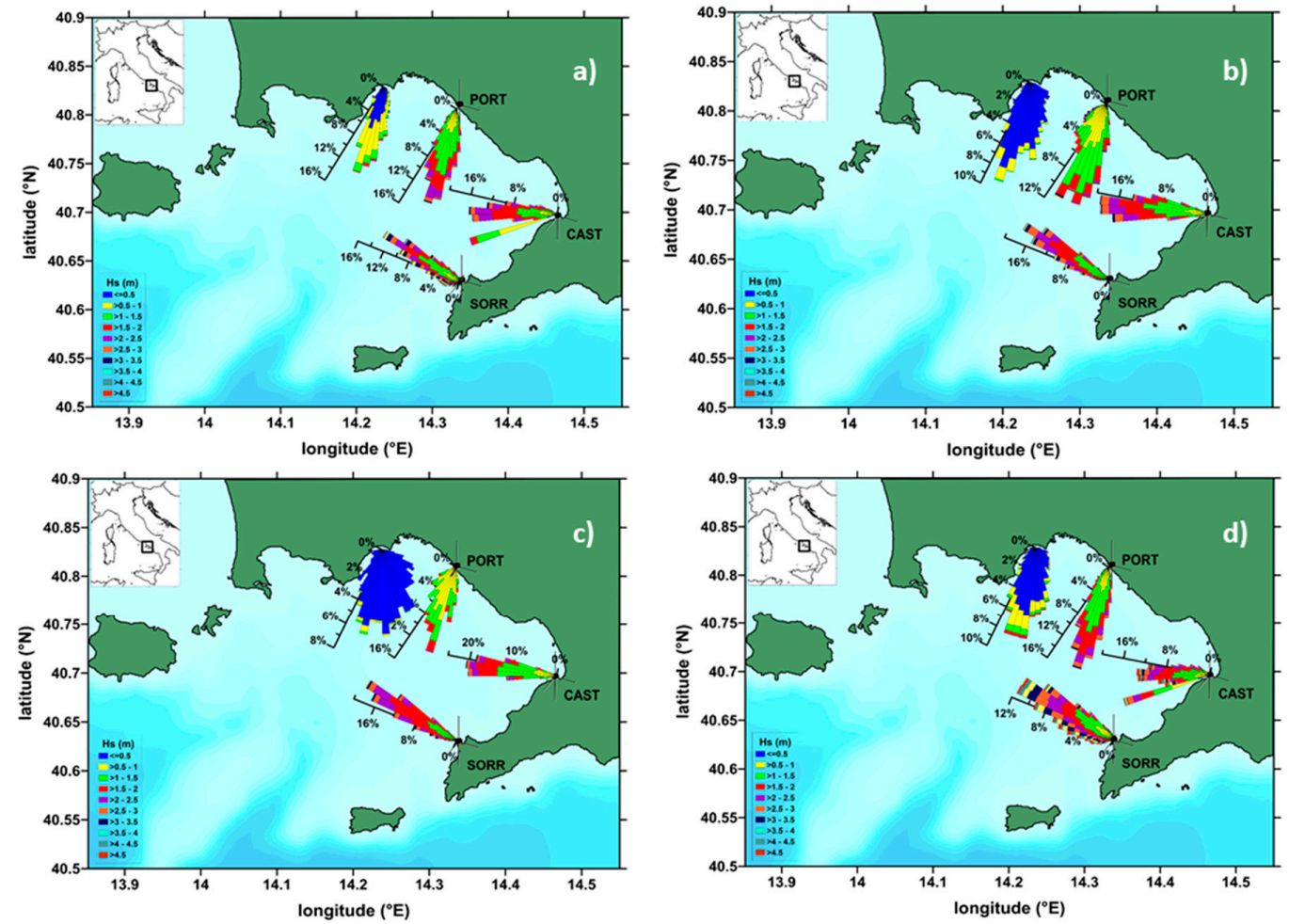

Figure 4. Seasonal wave rose diagrams for the HF radar and the ADCP entire dataset. The panels show the different seasons: (a) winter; (b) spring; (c) summer; and (d) autumn. The radial scale reports wave frequency, while each spoke is color-divided according to wave height ranges (see legend).

Table 3. Joint frequency distributions of the wave measurements (Hs and $\theta$ ) recorded by the ADCP and the HF radars. Data were grouped in eight $\mathrm{Hs}$ classes of $0.50 \mathrm{~m}$ each, and in direction sectors with an angle of $15^{\circ}$. For each combination of Hs and $\theta$ values, the number of occurrences was calculated.

\begin{tabular}{|c|c|c|c|c|c|c|c|c|c|c|c|c|c|c|c|c|c|}
\hline \multicolumn{18}{|c|}{ ADCP (November 2015-July 2018) } \\
\hline $\begin{array}{c}\text { Wave Direction } \\
(\operatorname{deg} N)\end{array}$ & 3454 & 2484 & 564 & 125 & 22 & 2 & 6 & $\mathbf{0}$ & 0 & 0 & 0 & 0 & 0 & 0 & 0 & 0 & 6655 \\
\hline 360 & - & - & - & - & - & - & - & - & - & - & - & - & - & - & - & - & - \\
\hline 345 & - & - & - & - & - & - & - & - & - & - & - & - & - & - & - & - & - \\
\hline 330 & - & - & - & - & - & - & - & - & - & - & - & - & - & - & - & - & - \\
\hline 315 & - & - & - & - & - & - & - & - & - & - & - & - & - & - & - & - & - \\
\hline 300 & - & - & - & - & - & - & - & - & - & - & - & - & - & - & - & - & - \\
\hline 285 & - & - & - & - & - & - & - & - & - & - & - & - & - & - & - & - & - \\
\hline 270 & - & - & - & - & - & - & - & - & - & - & - & - & - & - & - & - & - \\
\hline 255 & - & - & - & - & - & - & - & - & - & - & - & - & - & - & - & - & - \\
\hline 240 & 168 & 41 & 9 & 1 & 1 & 1 & - & - & - & - & - & - & - & - & - & - & 221 \\
\hline 225 & 190 & 53 & 13 & - & - & - & 3 & - & - & - & - & - & - & - & - & - & 259 \\
\hline 210 & 288 & 139 & 40 & 3 & - & 1 & - & - & - & - & - & - & - & - & - & - & 471 \\
\hline 195 & 541 & 395 & 94 & 27 & 3 & - & 3 & - & - & - & - & - & - & - & - & - & 1063 \\
\hline 180 & 857 & 794 & 209 & 60 & 13 & - & - & - & - & - & - & - & - & - & - & - & 1933 \\
\hline 165 & 958 & 843 & 172 & 33 & 4 & - & - & - & - & - & - & - & - & - & - & - & 2010 \\
\hline 150 & 288 & 157 & 22 & 1 & 1 & - & - & - & - & - & - & - & - & - & - & - & 469 \\
\hline 135 & 96 & 31 & 2 & - & - & - & - & - & - & - & - & - & - & - & - & - & 129 \\
\hline 120 & 35 & 21 & 1 & - & - & - & - & - & - & - & - & - & - & - & - & - & 57 \\
\hline 105 & 32 & 9 & 2 & - & - & - & - & - & - & - & - & - & - & - & - & - & 43 \\
\hline 90 & - & - & - & - & - & - & - & - & - & - & - & - & - & - & - & - & - \\
\hline
\end{tabular}


Table 3. Cont.

\begin{tabular}{|c|c|c|c|c|c|c|c|c|c|c|c|c|c|c|c|c|c|}
\hline 75 & - & - & - & - & - & - & - & - & - & - & - & - & - & - & - & - & - \\
\hline 60 & - & - & - & - & - & - & - & - & - & - & - & - & - & - & - & - & - \\
\hline 45 & - & - & - & - & - & - & - & - & - & - & - & - & - & - & - & - & - \\
\hline 30 & - & - & - & - & - & - & - & - & - & - & - & - & - & - & - & - & - \\
\hline 15 & - & - & - & - & - & - & - & - & - & - & - & - & - & - & - & - & - \\
\hline & 0.5 & 1 & 1.5 & 2 & 2.5 & 3 & 3.5 & 4 & 4.5 & 5 & 5.5 & 6 & 6.5 & 7 & 7.5 & 8 & \\
\hline \multicolumn{18}{|c|}{ Significant Wave Height (m) } \\
\hline \multicolumn{18}{|c|}{ PORT HF radar (May 2008-December 2012) } \\
\hline $\begin{array}{l}\text { Wave Direction } \\
\quad(\operatorname{deg} N)\end{array}$ & 78 & 2907 & 3739 & 1538 & 617 & 275 & 90 & 29 & 4 & 0 & 0 & 0 & 0 & 0 & 0 & 0 & 9277 \\
\hline 360 & - & - & - & - & - & - & - & - & - & - & - & - & - & - & - & - & - \\
\hline 345 & - & - & - & - & - & - & - & - & - & - & - & - & - & - & - & - & - \\
\hline 330 & - & - & - & - & - & - & - & - & - & - & - & - & - & - & - & - & - \\
\hline 315 & - & - & - & - & - & - & - & - & - & - & - & - & - & - & - & - & - \\
\hline 300 & - & - & - & - & - & - & - & - & - & - & - & - & - & - & - & - & - \\
\hline 285 & - & 1 & 1 & - & - & - & - & - & - & - & - & - & - & - & - & - & 2 \\
\hline 270 & 1 & 27 & 31 & 5 & 6 & 1 & 2 & - & - & - & - & - & - & - & - & - & 73 \\
\hline 255 & 1 & 126 & 94 & 25 & 16 & 9 & 14 & 1 & - & - & - & - & - & - & - & - & 286 \\
\hline 240 & 6 & 258 & 187 & 40 & 22 & 13 & 5 & 1 & - & - & - & - & - & - & - & - & 532 \\
\hline 225 & 22 & 522 & 538 & 134 & 45 & 35 & 9 & 8 & 1 & - & - & - & - & - & - & - & 1314 \\
\hline 210 & 26 & 992 & 1347 & 604 & 236 & 108 & 37 & 10 & 2 & - & - & - & - & - & - & - & 3362 \\
\hline 195 & 16 & 746 & 1164 & 536 & 221 & 84 & 13 & 5 & - & - & - & - & - & - & - & - & 2785 \\
\hline 180 & 6 & 225 & 368 & 188 & 69 & 24 & 10 & 4 & 1 & - & - & - & - & - & - & - & 895 \\
\hline 165 & - & 10 & 9 & 6 & 2 & 1 & - & - & - & - & - & - & - & - & - & - & 28 \\
\hline 150 & - & - & - & - & - & - & - & - & - & - & - & - & - & - & - & - & - \\
\hline 135 & - & - & - & - & - & - & - & - & - & - & - & - & - & - & - & - & - \\
\hline 120 & - & - & - & - & - & - & - & - & - & - & - & - & - & - & - & - & - \\
\hline 105 & - & - & - & - & - & - & - & - & - & - & - & - & - & - & - & - & - \\
\hline 90 & - & - & - & - & - & - & - & - & - & - & - & - & - & - & - & - & - \\
\hline 75 & - & - & - & - & - & - & - & - & - & - & - & - & - & - & - & - & - \\
\hline 60 & - & - & - & - & - & - & - & - & - & - & - & - & - & - & - & - & - \\
\hline 45 & - & - & - & - & - & - & - & - & - & - & - & - & - & - & - & - & - \\
\hline 30 & - & - & - & - & - & - & - & - & - & - & - & - & - & - & - & - & - \\
\hline \multirow[t]{2}{*}{15} & - & - & - & - & - & - & - & - & - & - & - & - & - & - & - & - & - \\
\hline & 0.5 & 1 & 1.5 & 2 & 2.5 & 3 & 3.5 & 4 & 4.5 & 5 & 5.5 & 6 & 6.5 & 7 & 7.5 & 8 & \\
\hline \multicolumn{18}{|c|}{ Significant Wave Height (m) } \\
\hline $\begin{array}{l}\text { Wave Direction } \\
\quad(\text { deg N) }\end{array}$ & 365 & 2878 & 3880 & 2623 & 1405 & 639 & 174 & 75 & 62 & 42 & 32 & 12 & 2 & 2 & 0 & 0 & 12.191 \\
\hline 360 & - & - & - & - & - & - & - & - & - & - & - & - & - & - & - & - & - \\
\hline 345 & - & - & - & - & - & - & - & - & - & - & - & - & - & - & - & - & - \\
\hline 330 & - & - & - & - & - & - & - & - & - & - & - & - & - & - & - & - & - \\
\hline 315 & 17 & 135 & 98 & 54 & 89 & 23 & 9 & 3 & - & - & - & - & - & - & - & - & 428 \\
\hline 300 & 71 & 526 & 650 & 368 & 213 & 93 & 19 & 18 & 2 & - & - & - & - & - & - & - & 1960 \\
\hline 285 & 66 & 1120 & 1882 & 1281 & 657 & 290 & 79 & 16 & 16 & 13 & 8 & 7 & - & 2 & - & - & 5437 \\
\hline 270 & 52 & 615 & 979 & 804 & 387 & 195 & 63 & 29 & 38 & 28 & 22 & 4 & 2 & - & - & - & 3218 \\
\hline 255 & 159 & 482 & 271 & 116 & 59 & 38 & 4 & 9 & 6 & 1 & 2 & 1 & - & - & - & - & 1148 \\
\hline 240 & - & - & - & - & - & - & - & - & - & - & - & - & - & - & - & - & - \\
\hline 225 & - & - & - & - & - & - & - & - & - & - & - & - & - & - & - & - & - \\
\hline 210 & - & - & - & - & - & - & - & - & - & - & - & - & - & - & - & - & - \\
\hline
\end{tabular}


Table 3. Cont.

\begin{tabular}{|c|c|c|c|c|c|c|c|c|c|c|c|c|c|c|c|c|c|}
\hline 195 & - & - & - & - & - & - & - & - & - & - & - & - & - & - & - & - & - \\
\hline 180 & - & - & - & - & - & - & - & - & - & - & - & - & - & - & - & - & - \\
\hline 165 & - & - & - & - & - & - & - & - & - & - & - & - & - & - & - & - & - \\
\hline 150 & - & - & - & - & - & - & - & - & - & - & - & - & - & - & - & - & - \\
\hline 135 & - & - & - & - & - & - & - & - & - & - & - & - & - & - & - & - & - \\
\hline 120 & - & - & - & - & - & - & - & - & - & - & - & - & - & - & - & - & - \\
\hline 105 & - & - & - & - & - & - & - & - & - & - & - & - & - & - & - & - & - \\
\hline 90 & - & - & - & - & - & - & - & - & - & - & - & - & - & - & - & - & - \\
\hline 75 & - & - & - & - & - & - & - & - & - & - & - & - & - & - & - & - & - \\
\hline 60 & - & - & - & - & - & - & - & - & - & - & - & - & - & - & - & - & - \\
\hline 45 & - & - & - & - & - & - & - & - & - & - & - & - & - & - & - & - & - \\
\hline 30 & - & - & - & - & - & - & - & - & - & - & - & - & - & - & - & - & - \\
\hline \multirow[t]{2}{*}{15} & - & - & - & - & - & - & - & - & - & - & - & - & - & - & - & - & - \\
\hline & 0.5 & 1 & 1.5 & 2 & 2.5 & 3 & 3.5 & 4 & 4.5 & 5 & 5.5 & 6 & 6.5 & 7 & 7.5 & 8 & \\
\hline \multicolumn{18}{|c|}{ Significant Wave Height (m) } \\
\hline \multicolumn{18}{|c|}{ SORR HF radar (May 2008-December 2012) } \\
\hline $\begin{array}{c}\text { Wave Direction } \\
\text { (deg N) }\end{array}$ & 158 & 2531 & 5488 & 4568 & 2795 & 1795 & 1364 & 755 & 437 & 167 & 56 & 31 & 28 & 16 & 4 & 0 & 20.193 \\
\hline 360 & 5 & 34 & 49 & 38 & 13 & 3 & 6 & 1 & 1 & 1 & - & - & - & - & - & - & 151 \\
\hline 345 & 6 & 121 & 167 & 84 & 45 & 15 & 12 & 2 & - & - & - & - & - & - & - & - & 454 \\
\hline 330 & 15 & 329 & 449 & 247 & 141 & 71 & 46 & 29 & 10 & 5 & 1 & - & - & - & - & - & 1343 \\
\hline 315 & 55 & 921 & 2224 & 1867 & 952 & 509 & 260 & 109 & 67 & 18 & 4 & 6 & 6 & 2 & - & - & 7000 \\
\hline 300 & 45 & 609 & 1729 & 1699 & 1038 & 617 & 376 & 206 & 104 & 35 & 6 & 7 & 3 & 6 & - & - & 6480 \\
\hline 285 & 7 & 239 & 476 & 421 & 374 & 330 & 331 & 178 & 105 & 50 & 20 & 9 & 7 & 5 & 2 & - & 2554 \\
\hline 270 & 4 & 89 & 161 & 123 & 162 & 177 & 227 & 159 & 92 & 29 & 19 & 3 & 9 & 3 & 2 & - & 1259 \\
\hline 255 & 3 & 66 & 94 & 63 & 46 & 59 & 92 & 58 & 46 & 25 & 5 & 5 & 2 & - & - & - & 564 \\
\hline 240 & 3 & 62 & 93 & 19 & 14 & 13 & 13 & 11 & 11 & 3 & 1 & - & - & - & - & - & 243 \\
\hline 225 & 7 & 22 & 22 & 4 & 3 & - & 1 & - & 1 & 1 & - & - & - & - & - & - & 61 \\
\hline 210 & 6 & 32 & 19 & 1 & 4 & 1 & - & 2 & - & - & - & - & - & - & - & - & 65 \\
\hline 195 & 2 & 6 & 5 & 2 & 2 & - & - & - & - & - & - & - & - & - & - & - & 17 \\
\hline 180 & - & 1 & - & - & 1 & - & - & - & - & - & - & - & - & - & - & - & 2 \\
\hline 165 & - & - & - & - & - & - & - & - & - & - & - & - & - & - & - & - & - \\
\hline 150 & - & - & - & - & - & - & - & - & - & - & - & - & - & - & - & - & - \\
\hline 135 & - & - & - & - & - & - & - & - & - & - & - & - & - & - & - & - & - \\
\hline 120 & - & - & - & - & - & - & - & - & - & - & - & - & - & - & - & - & - \\
\hline 105 & - & - & - & - & - & - & - & - & - & - & - & - & - & - & - & - & - \\
\hline 90 & - & - & - & - & - & - & - & - & - & - & - & - & - & - & - & - & - \\
\hline 75 & - & - & - & - & - & - & - & - & - & - & - & - & - & - & - & - & - \\
\hline 60 & - & - & - & - & - & - & - & - & - & - & - & - & - & - & - & - & - \\
\hline 45 & - & - & - & - & - & - & - & - & - & - & - & - & - & - & - & - & - \\
\hline 30 & - & - & - & - & - & - & - & - & - & - & - & - & - & - & - & - & - \\
\hline \multirow[t]{2}{*}{15} & - & - & - & - & - & - & - & - & - & - & - & - & - & - & - & - & - \\
\hline & 0.5 & 1 & 1.5 & 2 & 2.5 & 3 & 3.5 & 4 & 4.5 & 5 & 5.5 & 6 & 6.5 & 7 & 7.5 & 8 & \\
\hline \multicolumn{18}{|c|}{ Significant Wave Height (m) } \\
\hline
\end{tabular}



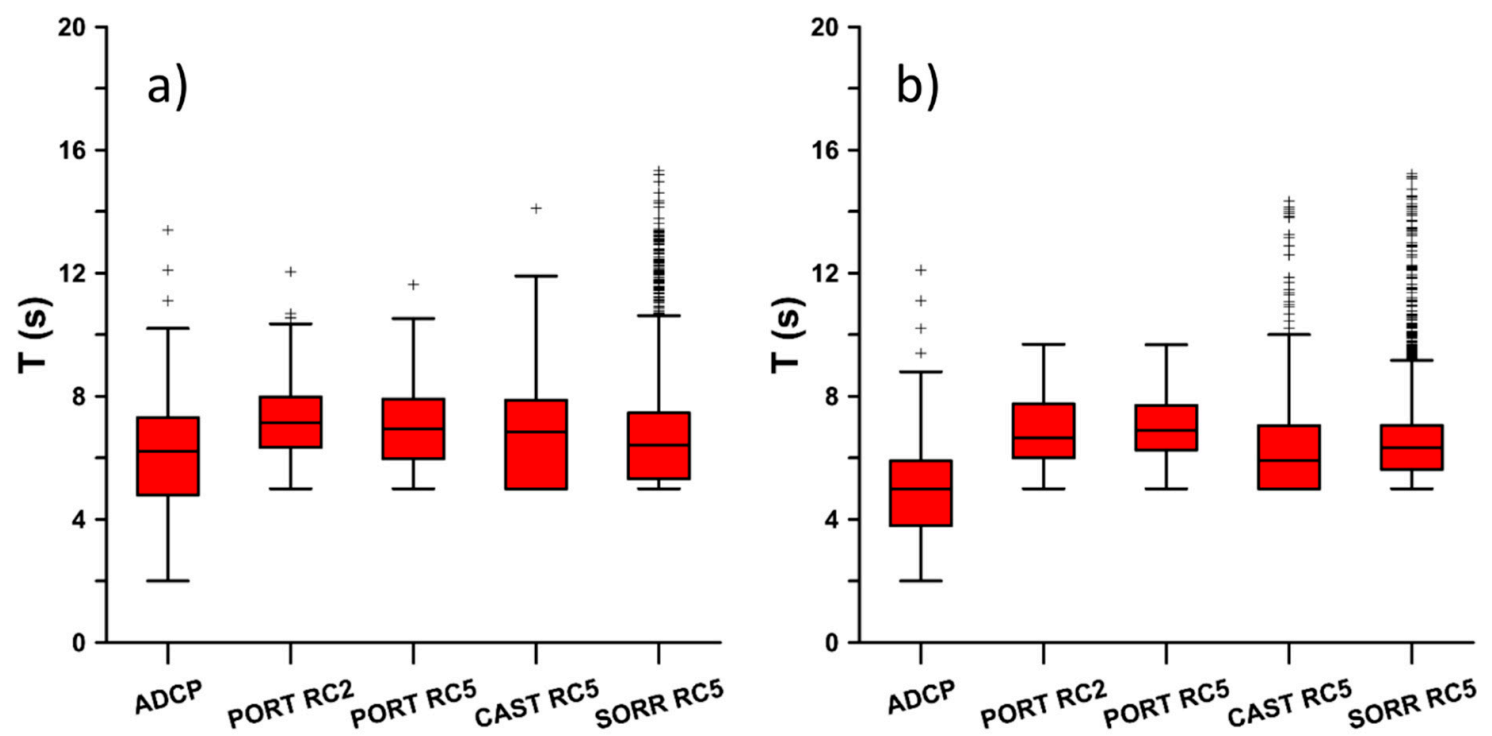

\section{WINTER}

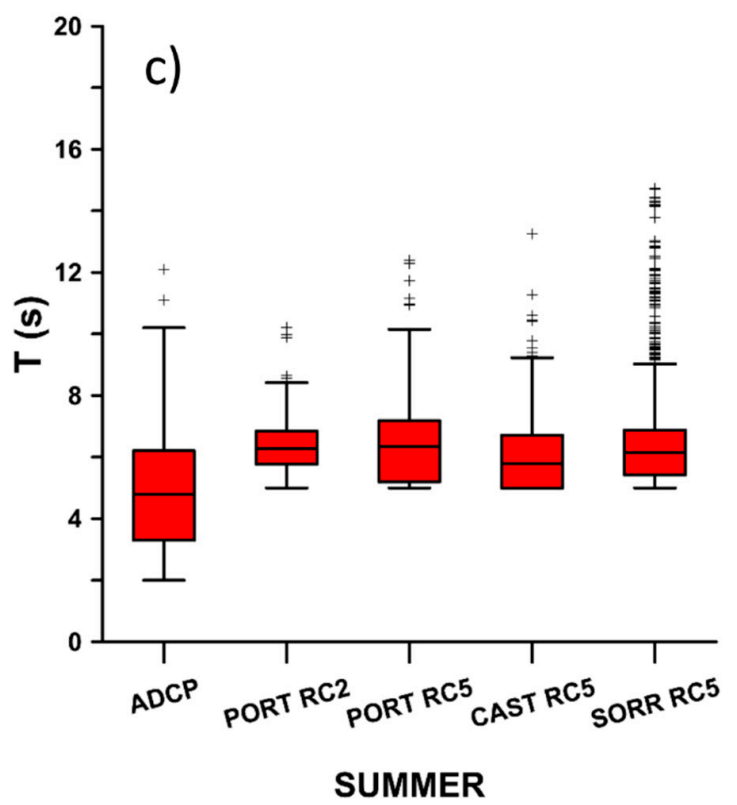

\section{SPRING}

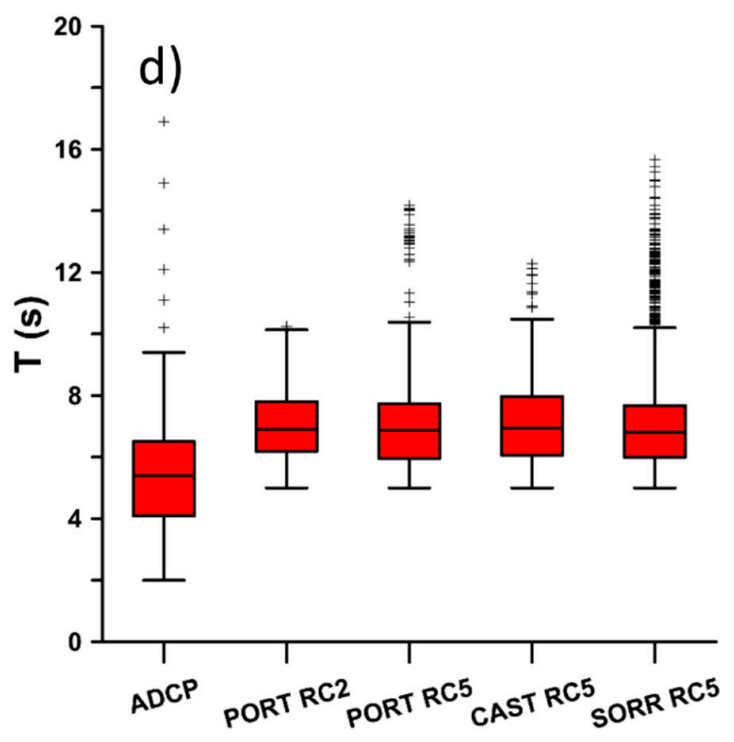

AUTUMN

Figure 5. Cumulative seasonal T boxplots recorded by the ADCP and the HF radars. For the PORT site, both RC2 and RC5 data are shown. The panels show the different seasons: (a) winter; (b) spring;

(c) summer; and (d) autumn.

\subsection{Analysis of Extreme Events}

During the sampled years, the HF radars and the ADCP recorded several storm events. Among the study cases selected, four events were selected and considered for the present investigation (Table 4): one recorded by the PORT and SORR HF radars (24-25 November 2008, total duration: $24 \mathrm{~h}$ ); one recorded by all three radar sites (10-11 January 2010, total duration: $36 \mathrm{~h}$ ); two recorded by the ADCP (28-29 February 2016, total duration: 32 h; 27-29 December 2017, total duration 45 h). Out of the possible events, the attention was focused on storms with a minimum duration of $24 \mathrm{~h}$, and which were considered particularly severe (i.e., determining the suspension of ferry boat service to the isles of the GoN).

The analysis of these events allowed us to investigate the wave energy content $(\mathrm{E})$ in different coastal sectors of the GoN. Unfortunately, the lack of temporal overlap between the ADCP and the HF radars prevented a direct comparison of the energy content measured by the two platforms. Despite 
this, some preliminary conclusions can be drawn from the analyzed events. First, as expected, the E values at SORR were always higher than the concomitant ones recorded at the innermost sites, in line with the site specificities outlined in the previous section. As a second outcome, the calculation based on ADCP data demonstrated that, even in the innermost sector of the GoN, the E associated with prolonged storms could reach scores comparable to those on farther offshore sectors during shorter events.

Table 4. Duration (h), Hs mean (m), and energy content $\mathrm{E}\left(\mathrm{m}^{2} \mathrm{~h}\right)$ of extreme events recorded by HF radars and ADCP.

\begin{tabular}{|c|c|c|c|c|}
\hline \multirow{2}{*}{$\begin{array}{r}\text { Event } \\
\text { Parameters }\end{array}$} & \multicolumn{2}{|c|}{$\begin{array}{c}1 \\
(24-25 / 11 / 08) \\
\text { Duration } 24 \mathrm{~h}\end{array}$} & \multicolumn{2}{|c|}{$\begin{array}{c}2 \\
(10-11 / 1 / 10) \\
\text { Duration } 36 \mathrm{~h}\end{array}$} \\
\hline & Hs mean $(\mathrm{m})$ & $E\left(m^{2} h\right)$ & Hs mean $(\mathrm{m})$ & $E\left(m^{2} h\right)$ \\
\hline PORT-RC2 & 1.79 & 85.29 & 1.47 & 77.29 \\
\hline PORT-RC5 & 2.24 & 118.29 & 1.59 & 92.80 \\
\hline CAST-RC5 & - & - & 1.75 & 116.23 \\
\hline SORR-RC5 & 3.52 & 316.93 & 2.32 & 234.40 \\
\hline Event & \multicolumn{2}{|c|}{$\begin{array}{c}3 \\
(28-29 / 02 / 16) \\
\text { Duration } 32 \mathrm{~h}\end{array}$} & \multicolumn{2}{|c|}{$\begin{array}{c}4 \\
(27-29 / 12 / 17) \\
\text { Duration } 45 \mathrm{~h}\end{array}$} \\
\hline Parameters & Hs mean $(\mathrm{m})$ & $E\left(m^{2} h\right)$ & Hs mean $(\mathrm{m})$ & $E\left(m^{2} h\right)$ \\
\hline ADCP & 1.85 & 122.85 & 1.49 & 109.48 \\
\hline
\end{tabular}

\section{Discussion}

An accurate knowledge of wave conditions in coastal basins is essential for a broad range of scientific as well as applied purposes (e.g., the study of coastal shoreline stability and the seasonal longshore migration of sediment, engineering activities, renewable energy and climate studies centered on air-sea interaction $[77,78])$.

A previous study on the wave climate in Italian seas showed different behaviors depending on the investigated areas, and classified the wave climate into two main regimes: the first characterized by bior multi-modal waves arriving from different sectors (as happens in the Ionian and Adriatic seas), while the second regime is characterized by unimodal patterns (Tyrrhenian Sea) [41]. In addition, the wave climate in the Tyrrhenian Sea varies strongly during the seasons, with low Hs (in the order of a few tens of centimeters) in summer replaced by waves up to $3 \mathrm{~m}$ during winter and autumn [41]. In this context, the results presented in this study show that the GoN adheres to this larger-scale regime. The multiple year analysis of the wave dataset recorded by the HF radar network (2008-2012) and by in situ measurements gathered by the ADCP (2015-2018) suggest that the wave field is predominantly locally wind-driven and, for each site, the wave data are coherent among the years, with specific patterns depending on the sub-basin of the GoN under analysis. The results presented in this contribution align with previous studies focused on shorter temporal windows [33,37-40,63], pointing out a strong seasonality of Hs related to the meteorological features of the study area. In addition, covering different sectors of the basin (each with peculiar geomorphological features and bathymetry), the integrated observation platform used here was able to recognize the different dynamics characterizing the internal and the external sub-regions of the GoN.

In terms of directionality, $\theta$ is strongly affected by the morphology of the GoN. The area closer to the Naples urban site (monitored by PORT HF radar and ADCP) is aligned with the main aperture of the GoN ("Bocca Grande", the channel separating Ischia and Capri islands), while the presence of Capri Island creates a shadow zone shielding the coastline covered by SORR and, to a lesser degree, the CAST antennas, as confirmed by recent comparisons between HF radar data and wave models [35]. 
For each site, the directional pattern was strongly unimodal, validating for the different sectors of the GoN the larger scale behavior discussed in [41]. In all cases, due to the relative closeness of the measurements to the coast, refraction appears to contribute substantially in letting the wave front approach the coast almost perpendicularly.

The comparison of $\mathrm{T}$ brings challenging results in the evaluation of the inter-platform performance. Previous literature indicates that $\mathrm{T}_{\mathrm{HF}}$ typically sits between the mean and the peak period retrieved by wave buoys [29,31], being a suitable indicator of the mean period $\mathrm{T}_{m}[29,31,34]$ as demonstrated also specifically for the GoN with both wave buoys [33] and models [35]. In the present analysis, the peak period $\mathrm{T}_{\mathrm{B}}$ returned by the ADCP showed values lower than $\mathrm{T}_{\mathrm{HF}}$ and displayed a greater statistical dispersion, as typical for peak periods that are noisier than mean ones [31]. This inconsistency may be attributed to specific instrument data retrieval and analysis processes, but to date has no previous literature background reference. It should also be considered that HF radar cannot detect waves with a period lower than $5 \mathrm{~s}$ [20,34], thus introducing another element of disalignment between the two platforms. As such, this specific topic deserves further studies to be investigated in detail.

Taken together, the results presented in this contribution depict specific and recurrent features in the wave field of the different sub-basins of the GoN. Due to its proximity to the outer sector of the GoN, the SORR site recorded the highest E values, while at CAST and PORT the strength of the wave field was reduced. Interestingly, the comparison of the measurements recorded by PORT and by the ADCP revealed differences despite their close vicinity. These differences were only in part mitigated when considering RC2 (i.e., the cell closer to the coast which could be analyzed in the HF radar dataset). As discussed in a previous section, this result is likely to be due to the reduction of Hs induced by refraction, mirrored in a $30^{\circ}$ rotation of the main lobe compared to PORT as well as by a more shielded position of the gauge. The robustness of HF radar measurements at RC5 has been recently validated through the comparison with wave models [35], supporting the reliability of these records. Future implementations will also address the validation of ADCP records with wave models, setting up a specific numerical benchmark. In addition, prospective developments of the physical infrastructure will permit the contemporary functioning of both platforms, thus allowing for a direct comparison of the measurements. These next steps will shed light on the details ruling the nearshore propagation of the field and the associated changes in wave parameters.

The Hs observations during the sea storms selected in this work were in agreement with previous studies for the same area [33,38-40]. According to the storm classification presented in [71], all selected events can be categorized as class I (weak), which are the most probable in terms of occurrence frequency, except for the event 1 at the SORR location that was categorized as class II (moderate) based on its $\mathrm{E}$ value. The differences observed among the HF observations as well as those between the HF and ADCP records, mirror the site-specific patterns highlighted in the time series analysis, but also reflect the importance of storm duration. As a second outcome, the calculation based on ADCP data demonstrated that, even in the innermost sector of the GoN, the E associated with prolonged storms could reach scores comparable to those on farther offshore sectors during shorter events. These aspects, here preliminarily addressed by resorting to a small subset of events, will be deepened in a future work by including a higher number of stormy conditions and by complementing the analysis with numerical simulations to better resolve the spatial variability of the wave field in the GoN.

HF radars typically present an optimal window of functioning in terms of detectable Hs. For a $25 \mathrm{MHz}$ system like the one installed in the GoN, this window ranges from $0.50 \mathrm{~m}$ to $4.00 \mathrm{~m}$. The results discussed in $[33,35]$, complemented with those presented here, show that HF measurements can be considered as sufficiently robust indicators of the wave field pattern even when $\mathrm{Hs}>4.00 \mathrm{~m}$ in the presence of storm events, upon application of appropriate QA/QC procedures. This aspect, however, needs further investigation, as demonstrated by comparative analysis with wave model simulations [35]. This operational window overlaps with the one guaranteeing the maximum efficiency of wave energy converters ( $\mathrm{Hs}>2.00 \mathrm{~m}$, as discussed in [78]). As such, HF radars candidate as eligible tools for the preliminary assessment of sites of interest for the installation of wave energy farms $[79,80]$. 
The adoption of the integrated approach tested in this contribution is compliant with the indications provided by [81] in relation to the development of the next-generation of marine observatories, favoring the integration of different sampling strategies. Further implementations may encompass the inclusion of additional platforms (e.g., X-band radars [82]) to retrieve an even more detailed description of the wave field in coastal areas. Aside from the specific results focusing on the dynamics of the GoN, the present study also provides wider-breath elements in relation to the potential use of HF radars as a long-term monitoring platform for wave fields. ADCPs have a well-documented track of records in surface wave measurements [83], whereas HF radars have a proven ability to measure surface currents accurately even over long temporal scales (e.g., [84,85]). In contrast, only a few works have used HF radar data to characterize the wave field over periods as long as almost two years [30-34]. The results presented here represent the first report of a multiannual analysis of wave data retrieved through a network of HF radars, setting a new standard for the operational applications of this technology.

In addition, by monitoring the wave field over long periods, HF radars demonstrate their eligibility as source of information for hindcast analyses as well as input for model projections. Implementations in the functioning of HF systems and in the methods of data retrieval and analysis [86-89] will enhance the robustness of the measurements, providing increasingly more precise information on ocean surface parameters.

\section{Conclusions}

Multiannual surface gravity wave data retrieved by HF radar measurements and in situ measurements by an ADCP were employed to describe and analyze the wave field of the GoN. The integrated acquisition revealed clear seasonal patterns and pointed to specific features, depending on the sub-basin analyzed. The approach used in the present paper represents, to the best of present knowledge, the first use of HF radars combined with ADCP measurements to reconstruct the wave climatology (at least partially, due to the limitation in the number of years of recording) of a coastal basin. The results demonstrate the ability of an integrated system to provide a detailed view of surface wave dynamics over a decade, and represent a spur to further integrations and implementations of current ocean observatories. The multiannual wave patterns depicted can provide useful information for stakeholders and policy managers for several applications (e.g., the design of port and marine infrastructures and the identification of sites suitable for wave energy farms.

Author Contributions: Methodology: S.S., D.C., F.C., and M.U.; Software: S.S.; Validation: S.S., D.C., and M.U.; Data curation: F.C. and S.S.; Writing review and editing: S.S., D.C., and M.U. and F.C.; Project administration: F.C., M.U., and E.Z. All authors have read and agreed to the published version of the manuscript.

Funding: This work was funded by the Flagship Project RITMARE (The Italian Research for the Sea) coordinated by the Italian National Research Council and funded by the Italian Ministry of Education, University and Research within the National Research Program 2011-2013 and the AQUILA project (Parthenope University internal grant) (CUP:I63C17000060005). EZ was partly supported by the Parthenope University internal individual research grant. MU was supported by an internal SZN grant. This work was partly supported by DORA, Deployable Optics for Remote sensing Applications (ARS01-00653), a project funded by MIUR-PON Research and Innovation/PNR 2015-2020.

Acknowledgments: The authors thank the Editor and anonymous Reviewers for critical discussion on an earlier version of the study. The Department of Science and Technology (formerly the Department of Environmental Sciences) of the Parthenope University of Naples operates the HF radar system on behalf of the AMRA consortium (formerly CRdC AMRA), a regional competence center for the analysis and monitoring of environmental risks. Our radar remote sites are hosted by the ENEA Centre of Portici, the Villa Angelina Village of High Education and Professional Training and La Villanella resort in Massa Lubrense, and the Fincantieri shipyard in Castellammare di Stabia, whose hospitality is gratefully acknowledged. Mention of trade names or commercial products does not constitute endorsement or recommendation. Technical support by Giovanni Zambardino provided invaluable support to the proper functioning of the HF radar system. Exchanges with Berardino Buonocore and Pierpaolo Falco were greatly appreciated.

Conflicts of Interest: The authors declare no conflicts of interest. 


\section{References}

1. Appendini, C.M.; Torres-Freyermuth, A.; Salles, P.; López-González, J.; Mendoza, E.T. Wave climate and trends for the Gulf of Mexico: A 30-yr wave hindcast. J. Clim. 2013, 27, 1619-1632. [CrossRef]

2. Wiegel, R.K. Oceanographical Engineering; Prentice Hall: Englewood Cliffs, NJ, USA, 1964; p. 532.

3. Herbich, J.B.; Walters, T. Wave climate. In Beaches and Coastal Geology; Schwartz, M.L., Ed.; Springer: Boston, MA, USA, 1982; pp. 855-856.

4. Chini, N.; Stansby, P.; Leake, J.; Wolf, J.; Roberts-Jones, J.; Lowe, J. The impact of sea level rise and climate change on inshore wave climate: A case study for East Anglia (UK). Coast. Eng. 2010, 57, 973-984. [CrossRef]

5. Semedo, A.; Weisse, R.; Behrens, A.; Sterl, A.; Bengtsson, L.; Günther, H. Projection of global wave climate change toward the end of the twenty-first century. J. Clim. 2013, 26, 8269-8288. [CrossRef]

6. Menéndez, M.; Méndez, F.J.; Izaguirre, C.; Luceño, A.; Losada, I.J. The influence of seasonality on estimating return values of significant wave height. Coast. Eng. 2009, 56, 211-219. [CrossRef]

7. Stefanakos, C.N.; Athanassoulis, G.A.; Cavaleri, L.; Bertotti, L.; Lefèvre, J.-M. Wind and wave climatology of the Mediterranean Sea. Part II: Wave statistics. In Proceedings of the 14th International Offshore and Polar Engineering Conference (ISOPE 2004), Toulon, France, 23-28 May 2004.

8. Izaguirre, C.; Méndez, F.J.; Menéndez, M.; Losada, I.J. Global extreme wave height variability based on satellite data. Geophys. Res. Lett. 2011, 38, L10607. [CrossRef]

9. Inghilesi, R.; Orasi, A.; Catini, F. The ISPRA Mediterranean coastal wave forecasting system: Evaluation and perspectives. J. Oper. Oceanogr. 2016, 9, 89-98. [CrossRef]

10. Collard, F.; Ardhuin, F.; Chapron, B. Extraction of coastal ocean wave fields from SAR images. IEEE J. Ocean. Eng. 2005, 30, 526-533. [CrossRef]

11. Quilfen, Y.; Chapron, B. Ocean surface wave-current signatures from satellite altimeter measurements. Geophys. Res. Lett. 2019, 46, 253-261. [CrossRef]

12. Stopa, J.E.; Cheung, K.F.; Tolman, H.L.; Chawla, A. Patterns and cycles in the climate forecast system reanalysis wind and wave data. Ocean Model. 2013, 70, 207-220. [CrossRef]

13. Galanis, G.; Hayes, D.; Zodiatis, G.; Chu, P.C.; Kuo, Y.H.; Kallos, G. Wave height characteristics in the Mediterranean Sea by means of numerical modeling, satellite data, statistical and geometrical techniques. Mar. Geophys. Res. 2012, 33, 1-15. [CrossRef]

14. Crombie, D. Doppler spectrum of sea echo at $13.56 \mathrm{mc} / \mathrm{s}$. Nature 1955, 681-682. [CrossRef]

15. Barrick, D.E. The ocean waveheight non directional spectrum from inversion of the HF sea echo Doppler spectrum. Remote Sens. Environ. 1977, 6, 201-227. [CrossRef]

16. Paduan, J.D.; Graber, H.C. Introduction to high-frequency radar: Reality and myth. Oceanography 1997, 10. [CrossRef]

17. Gurgel, K.-W.; Antonischki, G.; Essen, H.-H.; Schlick, T. Wellen Radar WERA: A new ground-wave HF radar for ocean remote sensing. Coast. Eng. 1999, 37, 219-234. [CrossRef]

18. Lopez, G.; Conley, D.C.; Greaves, D. Calibration, validation, and analysis of an empirical algorithm for the retrieval of wave spectra from HF radar sea echo. J. Atmos. Ocean. Technol. 2016, 33, 245-261. [CrossRef]

19. Barrick, D.E. The role of the gravity-wave dispersion relation in HF radar measurements of the sea surface. IEEE J. Ocean. Eng. 1986, 11, 286-292. [CrossRef]

20. Lipa, B.J.; Nyden, B. Directional wave information from the SeaSonde. IEEE J. Ocean Eng. 2005, 30, $221-231$. [CrossRef]

21. Lipa, B.J.; Barrick, D.; Isaacson, J.; Lilleboe, P.M. CODAR wave measurements from a North Sea semisubmersible. IEEE J. Ocean Eng. 1990, 15, 119-125. [CrossRef]

22. Wyatt, L.R. The ocean wave directional spectrum. Oceanography 1997, 10. [CrossRef]

23. Wyatt, L.R.; Thompson, S.P.; Burton, R.R. Evaluation of HF radar wave measurement. Coast. Eng. 1999, 37, 259-282. [CrossRef]

24. Wyatt, L.R.; Green, J.J.; Middleditch, A. HF radar data quality requirements for wave measurement. Coast. Eng. 2011, 58, 327-336. [CrossRef]

25. Siddons, L.; Wyatt, L.; Wolf, J. Assimilation of HF radar data into the SWAN wave model. J. Mar. Syst. 2009, 77, 312-324. [CrossRef]

26. Wyatt, L.R.; Green, J.J. Measuring high and low waves with HF radar. In Proceedings of the OCEANS 2009-EUROPE, Bremen, Germany, 11-14 May 2009; pp. 1-5. 
27. Jin, L.; Wen, B.; Zhou, H. A new method of wave mapping with HF radar. Int. J. Antennas Propag. $2016,1-7$. [CrossRef]

28. Lipa, B.J.; Barrick, D.E.; Bourg, J.; Nyden, B.B. HF radar detection of tsunamis. J. Oceanogr. 2006, 62, 705-716. [CrossRef]

29. Lipa, B.J.; Barrick, D.E.; Alonso-Martirena, A.; Fernandes, M.; Ferrer, M.I.; Nyden, B. Brahan project high frequency radar ocean measurements: Currents, winds, waves and their interactions. Remote Sens. 2014, 6, 12094-12117. [CrossRef]

30. Wyatt, L.R.; Green, J.J.; Middleditch, A.; Moorhead, M.D.; Howarth, J.; Holt, M.; Keogh, S. Operational wave, current and wind measurements with the Pisces HF radar. IEEE J. Ocean. Eng. 2006, 31, 819-834. [CrossRef]

31. Long, R.M.; Barrick, D.; Largier, J.L.; Garfield, N. Wave observations from central California: SeaSonde systems and in situ wave buoys. J. Sens. 2011, 1-18. [CrossRef]

32. Atan, R.; Goggins, J.; Harnett, M.; Agostinho, P.; Nash, S. Assessment of wave characteristics and resource variability at a 1/4-scale wave energy test site in Galway Bay using waverider and high frequency radar (CODAR) data. Ocean Eng. 2016, 117, 272-291. [CrossRef]

33. Saviano, S.; Kalampokis, A.; Zambianchi, E.; Uttieri, M. A year-long assessment of wave measurements retrieved from an HF radar network in the Gulf of Naples (Tyrrhenian Sea, Western Mediterranean Sea). J. Oper. Oceanogr. 2019, 12, 1-15. [CrossRef]

34. Basañez, A.; Lorente, P.; Montero, P.; Álvarez-Fanjul, E.; Pérez-Muñuzuri, V. Quality Assessment and practical interpretation of the wave parameters estimated by HF Radars in NW Spain. Remote Sens. 2020, 12, 598. [CrossRef]

35. de Leo, F.; Besio, G.; Saviano, S.; Zambianchi, E.; Uttieri, M. Evaluation of HF-radar wave measures in the Gulf of Naples. In Proceedings of the IMEKO TC19 International Workshop on Metrology for the Sea: Learning to Measure Sea Health Parameters (MetroSea 2019), Genova, Italy, 3-5 October 2019.

36. Rubio, A.; Mader, J.; Corgnati, L.; Mantovani, C.; Griffa, A.; Novellino, A.; Quentin, C.; Wyatt, L.; Schulz-Stellenfleth, J.; Horstmann, J. HF radar activity in European coastal seas: Next steps toward a pan-European HF radar network. Front. Mar. Sci. 2017, 4, 8. [CrossRef]

37. Pugliese Carratelli, E.; Sansone, E. Rilievi ondametrici nel Golfo di Napoli. Ann. IUN 1987, 50, 87-97.

38. Benassai, G.; de Maio, A.; Mainolfi, R.; Sansone, E. Previsione delle onde estreme e persistenza delle mareggiate nel Golfo di Napoli. Ann. IUN 1994, 61, 47-60.

39. Benassai, G.; de Maio, A.; Sansone, E. Altezze e periodi delle onde significative nel Golfo di Napoli dall'aprile 1986 al giugno 1987. Ann. IUN 1994, 61, 3-9.

40. Buonocore, B.; Sansone, E.; Zambardino, G. Rilievi ondametrici nel Golfo di Napoli. Ann. IUN 2003, 67, 203-211.

41. Morucci, S.; Picone, M.; Nardone, G.; Arena, G. Tides and waves in the Central Mediterranean Sea. J. Oper. Oceanogr. 2016, 9, 10-17. [CrossRef]

42. Cianelli, D.; Uttieri, M.; Buonocore, B.; Falco, P.; Zambardino, G.; Zambianchi, E. Dynamics of a very special Mediterranean coastal area: The Gulf of Naples. In Mediterranean Ecosystems; Williams, G.S., Ed.; Nova Science Publishers Inc.: New York, NY, USA, 2012; pp. 129-150.

43. De Maio, A.; Moretti, M.; Sansone, E.; Spezie, G.; Vultaggio, M. Outline of marine currents in the Bay of Naples and some considerations on pollutant transport. Nuovo Cim. C 1985, 8, 955-969. [CrossRef]

44. Moretti, M.; Sansone, E.; Spezie, G.; Vultaggio, M.; De Maio, A. Alcuni aspetti del movimento delle acque del Golfo di Napoli. Ann. IUN 1976, 45-46, 207-217.

45. Arienzo, M.; Donadio, C.; Mangoni, O.; Bolinesi, F.; Stanislao, C.; Trifuoggi, M.; Toscanesi, M.; Di Natale, G.; Ferrara, L. Characterization and source apportionment of polycyclic aromatic hydrocarbons (pahs) in the sediments of gulf of Pozzuoli (Campania, Italy). Mar. Pollut. Bull. 2017, 124, 480-487. [CrossRef]

46. Qu, C.; Albanese, S.; Lima, A.; Hope, D.; Pond, P.; Fortelli, A.; Romano, N.; Cerino, P.; Pizzolante, A.; De Vivo, B. The occurrence of OCPs, PCBs, and PAHs in the soil, air, and bulk deposition of the Naples metropolitan area, southern Italy: Implications for sources and environmental processes. Environ. Int. 2019, 124, 89-97. [CrossRef]

47. Mercogliano, R.; Santonicola, S.; De Felice, A.; Anastasio, A.; Murru, N.; Ferrante, M.C.; Cortesi, M.L. Occurrence and distribution of polycyclic aromatic hydrocarbons in mussels from the gulf of Naples, Tyrrhenian Sea, Italy. Mar. Pollut. Bull. 2016, 104, 386-390. [CrossRef] [PubMed] 
48. Trifuoggi, M.; Donadio, C.; Mangoni, O.; Ferrara, L.; Bolinesi, F.; Nastro, R.A.; Stanislao, C.; Toscanesi, M.; Di Natale, G.; Arienzo, M. Distribution and enrichment of trace metals in surface marine sediments in the Gulf of Pozzuoli and off the coast of the brownfield metallurgical site of Ilva of Bagnoli (Campania, Italy). Mar. Pollut. Bull. 2017, 124, 502-511. [CrossRef] [PubMed]

49. Bavestrello, G.; Bo, M.; Canese, S.; Sandulli, R.; Cattaneo-Vietti, R. The red coral populations of the gulfs of Naples and Salerno: Human impact and deep mass mortalities. Ital. J. Zool. 2014, 81, 552-563. [CrossRef]

50. Ferrigno, F.; Appolloni, L.; Russo, G.F.; Sandulli, R. Impact of fishing activities on different coralligenous assemblages of Gulf of Naples (Italy). J. Mar. Biol. Assoc. UK 2018, 98, 41-50. [CrossRef]

51. Donnarumma, L.; Appolloni, L.; Chianese, E.; Bruno, R.; Baldrighi, E.; Guglielmo, R.; Russo, G.F.; Zeppilli, D.; Sandulli, R. Environmental and benthic community patterns of the shallow hydrothermal area of Secca delle Fumose (Baia, Naples, Italy). Front. Mar. Sci. 2019, 6, 685. [CrossRef]

52. Polese, G.; Semprucci, F.; Campoli, L.; Maselli, V.; Ribera d'Alcalà, M.; Balsamo, M.; Di Cosmo, A. Meiofaunal assemblages of the bay of Nisida and the environmental status of the Phlegraean area (Naples, Southern Italy). Mar. Biodiv. 2018, 48, 127. [CrossRef]

53. Crocetta, F.; Riginella, E.; Lezzi, M.; Tanduo, V.; Balestrieri, L.; Rizzo, L. Bottom-trawl catch composition in a highly polluted coastal area reveals multifaceted native biodiversity and complex communities of fouling organisms on litter discharge. Mar. Environ. Res. 2020, 155, 104875. [CrossRef]

54. Mattei, G.; Rizzo, A.; Anfuso, G.; Aucelli, P.P.C.; Gracia, F.J. A tool for evaluating the archaeological heritage vulnerability to coastal processes: The case study of Naples Gulf (southern Italy). Ocean Coast. Manag. 2019, 179, 104876. [CrossRef]

55. Mattei, G.; Rizzo, A.; Anfuso, G.; Aucelli, P.P.C.; Gracia, F.J. Enhancing the protection of archaeological sites as an integrated coastal management strategy: The case of the Posillipo Hill (Naples, Italy). Rend. Fis. Acc. Lincei 2020, 31, 139-152. [CrossRef]

56. Aucelli, P.P.C.; Mattei, G.; Caporizzo, C.; Cinque, A.; Troisi, S.; Peluso, F.; Stefanile, M.; Pappone, G. Ancient coastal changes due to ground movements and human interventions in the Roman Portus Julius (Pozzuoli Gulf, Italy): Results from photogrammetric and direct surveys. Water 2020, 12, 658. [CrossRef]

57. Buonocore, E.; Donnarumma, L.; Appolloni, L.; Miccio, A.; Russo, G.F.; Franzese, P.P. Marine natural capital and ecosystem services: An environmental accounting model. Ecol. Model. 2020, 424. [CrossRef]

58. Uttieri, M.; Cianelli, D.; Buongiorno Nardelli, B.; Buonocore, B.; Falco, P.; Colella, S.; Zambianchi, E. Multiplatform observation of the surface circulation in the Gulf of Naples (Southern Tyrrhenian Sea). Ocean Dyn. 2011, 61, 779-796. [CrossRef]

59. de Ruggiero, P. A high-resolution ocean circulation model of the Gulf of Naples and adjacent areas. Nuovo Cim. C 2013, 36, 143-150. [CrossRef]

60. de Ruggiero, P.; Napolitano, E.; Iacono, R.; Pierini, S. A high-resolution modelling study of the circulation along the Campania coastal system, with a special focus on the Gulf of Naples. Cont. Shelf Res. 2016, 122, 85-101. [CrossRef]

61. Cianelli, D.; Falco, P.; Iermano, I.; Mozzillo, P.; Uttieri, M.; Buonocore, B.; Zambardino, G.; Zambianchi, E. Inshore/offshore water exchange in the Gulf of Naples. J. Mar. Syst. 2015, 145, 37-52. [CrossRef]

62. Cianelli, D.; D'Alelio, D.; Uttieri, M.; Sarno, D.; Zingone, A.; Zambianchi, E.; Ribera d'Alcalà, M. Disentangling physical and biological drivers of phytoplankton dynamics in a coastal system. Sci. Rep. 2017, 7, 15868. [CrossRef]

63. Falco, P.; Buonocore, B.; Cianelli, D.; De Luca, L.; Giordano, A.; Iermano, I.; Kalampokis, A.; Saviano, S.; Uttieri, M.; Zambardino, G. Dynamics and sea state in the Gulf of Naples: Potential use of high-frequency radar data in an operational oceanographic context. J. Oper. Oceanogr. 2016, 9, 33-45. [CrossRef]

64. Menna, M.; Mercatini, A.; Uttieri, M.; Buonocore, B.; Zambianchi, E. Wintertime transport processes in the Gulf of Naples investigated by HF radar measurements of surface currents. Nuovo Cim. 2007, 30, 605-622.

65. Bartzokas, A. Annual variation of pressure over the Mediterranean area. Theor. Appl. Climatol. 1989, 40, 135. [CrossRef]

66. Hatzaki, M.; Flocas, H.A.; Simmonds, I.; Kouroutzoglou, J.; Keay, K.; Rudeva, I. Seasonal aspects of an objective climatology of anticyclones Affecting the Mediterranean. J. Clim. 2014, 27, 9272-9289. [CrossRef]

67. Mazzarella, V.; Maiello, I.; Ferretti, R.; Capozzi, V.; Picciotti, E.; Alberoni, P.P.; Marzano, F.S.; Budillon, G. Reflectivity and velocity radar data assimilation for two flash flood events in central Italy: A comparison between 3D and 4D variational methods. Q. J. R. Meteorol. Soc. 2019, 1-19. [CrossRef] 
68. Iermano, I.; Moore, A.M.; Zambianchi, E. Impacts of a 4-dimensional variational data assimilation in a coastal ocean model of southern Tyrrhenian Sea. J. Mar. Syst. 2016, 154, 157-171. [CrossRef]

69. Glickman, T.S. Glossary of Meteorology, 2nd ed.; American Meteorological Society: Boston, MA, USA, 2000.

70. Demirel, H.; Kompil, M.; Nemry, F. A framework to analyze the vulnerability of European road networks due to Sea-Level Rise (SLR) and sea storm surges. Transp. Res. A Policy Pract. 2015, 81, 62-76. [CrossRef]

71. Mendoza, E.T.; Jimenez, J.A.; Mateo, J. A coastal storms intensity scale for the Catalan sea (NW Mediterranean). Nat. Hazards Earth Syst. Sci. 2011, 11, 2453-2462. [CrossRef]

72. Molina, R.; Manno, G.; Lo Re, C.; Anfuso, G.; Ciraolo, G. Storm energy flux characterization along the Mediterranean coast of Andalusia (Spain). Water 2019, 11, 509. [CrossRef]

73. Hudak, D.R.; Young, J.M.C. Storm climatology of the Southern Beaufort sea. Atmos. Ocean 2002, 40, 145-158. [CrossRef]

74. Atan, R.; Goggins, J.; Harnett, M.; Nash, S.; Agostinho, P. Assessment of extreme wave height events in Galway Bay using high frequency radar (CODAR) data. In Renewable Energies Offshore; CRC Press: Boca Raton, FL, USA, 2015; pp. 49-56. [CrossRef]

75. Dally, W.R. Surf Zone Processes. Encyclopedia of Earth Science Series; In Encyclopedia of Coastal Science; Schwartz, M.L., Ed.; Springer: Dordrecht, The Netherlands, 2005.

76. Laws, K.; Paduan, J.D.; Vesecky, J. Estimation and assessment of errors related to antenna pattern distortion in CODAR SeaSonde high-frequency radar ocean current measurements. J. Atmos. Ocean. Technol. 2010, 27, 1029-1043. [CrossRef]

77. Wolf, J.; Woolf, D.K. Waves and climate change in the north-east Atlantic. Geophys. Res. Lett. 2006, 33 , L06604. [CrossRef]

78. Vicinanza, D.; Contestabile, P.; Ferrante, V. Wave energy potential in the north-west of Sardinia (Italy). Renew. Energy 2013, 50, 506-521. [CrossRef]

79. Wyatt, L.R. Wave power measurements in the Celtic Sea using HF radar. In Proceedings of the OCEANS 2017, Aberdeen, UK, 19-22 June 2017; pp. 1-4. [CrossRef]

80. Wyatt, L.R. Wave and tidal power measurement using HF radar. Int. Mar. Energy J. 2018, 1, $123-127$. [CrossRef]

81. Crise, A.; Ribera d'Alcalà, M.; Mariani, P.; Petihakis, G.; Robidart, J.; Iudicone, D.; Bachmayer, R.; Malfatti, F. A Conceptual framework for developing the next generation of Marine OBservatories (MOBs) for science and society. Front. Mar. Sci. 2018, 5, 318. [CrossRef]

82. Ludeno, G.; Serafino, F. Estimation of the significant wave height from marine radar images without external reference. J. Mar. Sci. Eng. 2019, 7, 432. [CrossRef]

83. Rao, L.; Wang, C.; Deng, K.; Zhang, Z.; Lu, S. Surface wave measurement with ADCP: A review of publications from 1979 to 2017. In Proceedings of the OCEANS 2017, Anchorage, AK, USA, 18-21 September 2017; pp. 1-7.

84. Ren, L.; Miao, J.; Li, Y.; Luo, X.; Li, J.; Hartnett, M. Estimation of coastal currents using a soft computing method: A case study in Galway Bay, Ireland. J. Mar. Sci. Eng. 2019, 7, 157. [CrossRef]

85. Lorente, P.; Basañez Mercader, A.; Piedracoba, S.; Pérez-Muñuzuri, V.; Montero, P.; Sotillo, M.G.; Álvarez-Fanjul, E. Long-term skill assessment of SeaSonde radar-derived wave parameters in the Galician coast (NW Spain). Int. J. Remote Sens. 2019, 40. [CrossRef]

86. Cosoli, S. Implementation of the listen-before-talk mode for SeaSonde High-Frequency ocean radars. J. Mar. Sci. Eng. 2020, 8, 57. [CrossRef]

87. Lopez, G.; Conley, D.C. Comparison of HF radar fields of directional wave spectra against in situ measurements at multiple locations. J. Mar. Sci. Eng. 2019, 7, 271. [CrossRef]

88. Lipa, B.; Barrick, D.; Whelan, C. A quality control method for broad-beam HF radar current velocity measurements. J. Mar. Sci. Eng. 2019, 7, 112. [CrossRef]

89. Hardman, R.L.; Wyatt, L.R. Inversion of HF radar Doppler spectra using a neural network. J. Mar. Sci. Eng. 2019, 7, 255. [CrossRef]

(C) 2020 by the authors. Licensee MDPI, Basel, Switzerland. This article is an open access article distributed under the terms and conditions of the Creative Commons Attribution (CC BY) license (http://creativecommons.org/licenses/by/4.0/). 